\title{
Media Ecology: The Competition of Local Private Television on Seizing Audiences for Broadcasting Sustainability in South Kalimantan, Indonesia
}

\author{
Atika Rusli*, Achmad Bayu Chandrabuwono, Muhammad Febri Rahmat Akbari \\ Lambung Mangkurat University, Banjarmasin, Indonesia \\ atika_rusli@ulm.ac.id, bayuchandra569@gmail.com
}

\begin{abstract}
Media ecology examined the interrelationships between the media and their supporting environment. This research article aimed to determine the category of life-support sources (niche breadth) and to measure the level of competition (niche overlap) of local private television in South Kalimantan in seizing for viewers. This research used a quantitative approach. Target audience data, as the main data, was obtained by data collection techniques in the form of logbook survey results or management estimates from each television. The collected data was processed using the niche breadth formula to determine the category of each television media, and the niche overlap formula to determine the level of television competition in seizing for its viewers. The findings showed that Duta TV was in the generalist category and Prima TV was in the specialist category. The niche overlap scores differed between a number of target audience types, where the level of competition in seizing for viewers between the two televisions was quite high in the gender category compared to the other four types of target audiences, namely age group, socioeconomic status, recent education, and occupation.
\end{abstract}

Keywords: Media ecology, television competition, niche theory, niche breadth, niche overlap.

\section{Introduction}

The existence of television stations in the regions, both local television stations and networked television stations, is expected to be able to compete to meet the needs of the people in that area. Morissan (2015) reveals that one of the weaknesses of the network system is the absence of local creativity and local genius in the broadcast realm. The network system makes local stations lack the motivation and creativity to produce, and develop local programs, including regional issues. The regional issues are less elevated and even regional cultural values are neglected. This is in line with the findings of Atika et al. (2021) that $90 \%$ of 20 televisions in South Kalimantan have limitations in broadcasting information local content-based programs. Television competition, both between local television and between networked national televisions can be analyzed with niche theory. Niche theory is used to measure media competition, which according to this theory, to maintain the survival of every living being requires a source of support that exists in the surrounding nature. If the required supporting resources are limited, then there will be competition or struggle between living beings. Similarly, with the media, if the source of media life support is limited in a region, then there will be competition or struggle for life support resources. Local television has the power to attract audiences with an approach and a feed of local content that suits the needs of the people in the region.

A number of studies have revealed how local television stations package their broadcasts as an attraction to grab viewers' attention. Priyowidodo (2009) reveals some examples from local television stations such as Bali TV, Yogya TV, and Borobudur TV very clearly directed the broadcast to audience segments which are bounded by local culture. Similarly, Favorite TV (Padang) for example also worked on Minang typical broadcast customs so that interested viewers and small-scale advertising can enter. TV Manado (TVM), TOP (Papuan Television) TV also tries to show the humor typical of North Sulawesi and Papua which is quite difficult to find on national television shows. Primasanti (2012) reveals that the diversity of content from local television that elevates diverse locality elements from various regions became the spearhead of democratization through broadcast media. Niche theory is used to measure the level of competition between mass media. Niche theory arises from the ecology study discipline that saying in order to maintain survival, a supporting source is needed in the environment. If the number of life supporting resources is limited then there will be competition. A media that utilizes the same resources or similar to other media then both media have a strong competition, and vice versa if the media utilizes different resources then it shows lower competition (Dimmick, 2008). This research article aimed to determine the category of life support sources (niche breadth) and to measure the level of competition (niche overlap) of local private television in South Kalimantan in seizing audiences. 


\section{Literature Review}

Media ecology research has been conducted with a number of different media and supporting resource focuses. Some of them are still partial, with not covering all the main sources of media life support, 2017 there was a research that measures the niche breadth of three news media namely yahoo, television, and electronic newspapers (Li, 2017a), then in the same year produced findings of television competition in the form of new media and old media namely OTT TV (over-the-top) which is a video service broadcast through the internet, IPTV (Internet Protocol TV) is a television that is broadcast using internet protocol, and digital cable TV (Li, 2017b). In 2019, there was research on the competition between internet television and traditional TV or cable television (Katherine Chen, 2019). Research using niche theory has also been conducted in broadcast media (radio and television) as well as print media in Indonesia, namely in 2009 which analyzed radio programs in Malang city (Hidayati, 2009), 2010 the findings that measured the competition of advertising broadcasting on three radios namely Kudus FM, Pamira FM, and Yasika FM (Yudiningrum, 2010), in 2012 the results of research on national private television station competition (Winanti Riesardhy \& Herawati, 2013). Research on television competition was also conducted by Dwinta Kusuma (2017), Hamid (2017), Irawan (2012), and Rinowati Na (2012).

The latest findings on media ecology are the ecology of public television media (Atika et al., 2020) and the ecology of private television media in terms of local information programs in South Kalimantan, which found that the level of competition of local television was high in terms of local-based content information programs (Atika et al., 2021). This idealism about locality is reflected in three things, namely conceptual, resource, and technical aspects of the broadcast. In contrast to a number of previous findings on media ecology, this article is the result of a follow-up study that previously analyzed media ecology based on local content-based information programs, while this article reveals the audience or target audience type as one of the main sources of television life support. The target audience type category analyzed is demographic segmentation (Morissan, 2015) reveals that audience segmentation based on demographics consists of age, gender, size of family members, highest education achieved, type of work, income level, religion, ethnicity, and so on. The category of target audience used in this article is adjusted to the data required to each television that will apply for a license to broadcast, namely based on the Regulation of the Minister of Communication and Informatics No. 28 of 2013 concerning Procedures and Licensing Requirements for The Implementation of Digital Television Broadcasting Services Through Terrestrial Systems, as presented in Table 1.

Table 1: The Television Target Audience Category

\begin{tabular}{|c|c|c|c|c|}
\hline \multicolumn{5}{|c|}{ Category of Target Audience Types } \\
\hline Age Group & Gender & $\begin{array}{l}\text { Social-economic } \\
\text { status (monthly } \\
\text { expense in IDR) }\end{array}$ & Latest education & Occupation \\
\hline $\begin{array}{l}<15 \text { Years old } \\
15-19 \text { Years old } \\
20-24 \text { Years old } \\
25-29 \text { Years old } \\
30-34 \text { Years old } \\
35-39 \text { Years old } \\
40-50 \text { Years old } \\
>50 \text { Years old }\end{array}$ & $\begin{array}{l}\text { Male } \\
\text { Female }\end{array}$ & $\begin{array}{l}>3.000 .000 \\
2.000 .001-3.000 .000 \\
1.000 .001-2.000 .000 \\
700.001-1.000 .000 \\
500.001-700.000 \\
<500.000\end{array}$ & $\begin{array}{l}\text { Did not complete } \\
\text { elementary school } \\
\text { Graduated from } \\
\text { elementary school } \\
\text { Graduated from junior } \\
\text { high school } \\
\text { Graduated from high } \\
\text { school } \\
\text { Academy } \\
\text { College }\end{array}$ & $\begin{array}{l}\text { Civil Servant/ } \\
\text { Army/ Police } \\
\text { Private Employees } \\
\text { Self-employed } \\
\text { Retired } \\
\text { Student } \\
\text { Student } \\
\text { Housewife } \\
\text { Other } \\
\text { Jobless }\end{array}$ \\
\hline
\end{tabular}

Table 1 shows five categories of target audience types that become media life support resources. Each of these categories has an indicator of different numbers, where the age group consists of eight indicators, the gender consists of two indicators, the social-economic status consists of six indicators, the last education consists of six indicators, and the work consists of nine indicators. All categories and indicators are measured to see the competition of local private television in seizing for viewers. (Morissan, 2015) writes that broadcast media competition is a competition to grab the attention of audiences, so broadcasters must 


\section{Journal of Social and Development Sciences (ISSN 2221-1152)}

Vol. 12, No. 2, pp. 20-26, June 2021

understand who and what their audience needs. Since 2005, several television stations in Indonesia began to segment and attempt to direct the program to a specific target audience.

\section{Research Methodology}

The research used a quantitative approach, with the research objects namely Duta TV and Prima TV which is a local private television station in South Kalimantan. Target audience data of television stations in South Kalimantan was quantitative data obtained by data collection techniques in the form of logbook survey results or management estimates from each television. The data that has been collected will be processed and analyzed using the following formula:

- To determine the category of supporting sources based on the type of target audience of each television (niche breadth), using the formula:

Niche Breadth: $\frac{\mathrm{I}}{\sum_{\mathrm{i}=1}^{\mathrm{n}} \mathrm{PI}^{2}}$

$\mathrm{I}=$ type /category of supporting sources used by television

$\mathrm{P}=$ proportion of each use of a type of supporting source used by television

Televisions that were close to the maximum value of supporting sources based on the type of target audience categorized as Generalist televisions, on the other hand, televisions that have a low breadth niche value categorized as Specialist televisions, as seen in table 2.

Table 2: Specialist and Generalist Scores Based on Target Audience Type

\begin{tabular}{lllllll}
\hline No & Target Audience Type & Min & Max & Interval & Category & \\
\cline { 5 - 6 } & & & & Specialist & Generalist \\
\hline 1 & Age group & 1 & 8 & 3.5 & $1.0-4.5$ & $4.6-8.0$ \\
2 & Gender & 1 & 2 & 0.5 & $1.0-1.5$ & $1.6-2.0$ \\
3 & Social Economic Status & 1 & 6 & 2.5 & $1.0-3.5$ & $3.6-6.0$ \\
4 & Latest Education & 1 & 6 & 2.5 & $1.0-3.5$ & $3.6-6.0$ \\
5 & Occupation & 1 & 9 & 4 & $1.0-5.0$ & $5.1-9.0$ \\
\hline
\end{tabular}

- To measure the level of competition between television pairs (niche overlap), it used the formula: Niche Overlap: $\frac{\mathrm{n}}{\mathrm{di}, \mathrm{j}}=\frac{\sum(\mathrm{pi} h-\mathrm{pj} h)^{2}}{h=1}$

di, $\mathrm{j}=$ distance/overlap between population (I) and (j) calculated by summing the degree of difference between the usage proportion of each category type (h).

$\mathrm{p}=$ proportion of resource usage

$\mathrm{h}=$ categories of resources used by both populations where the resource type reaches $\mathrm{n}$ categories

The level of competition will be seen from the calculation of television pairs. If the result is closer to zero, then on the television pair there is a high competition in seizing audience and vice versa.

\section{Data Analysis and Results}

The findings showed breadth and niche overlap scores of each television media based on the type of target audience. Figure 1 shows a niche score of breadth or supporting sources owned by local private television. 
Figure 1: Niche Breadth Score of Local Private Television Based on Target Audience Type

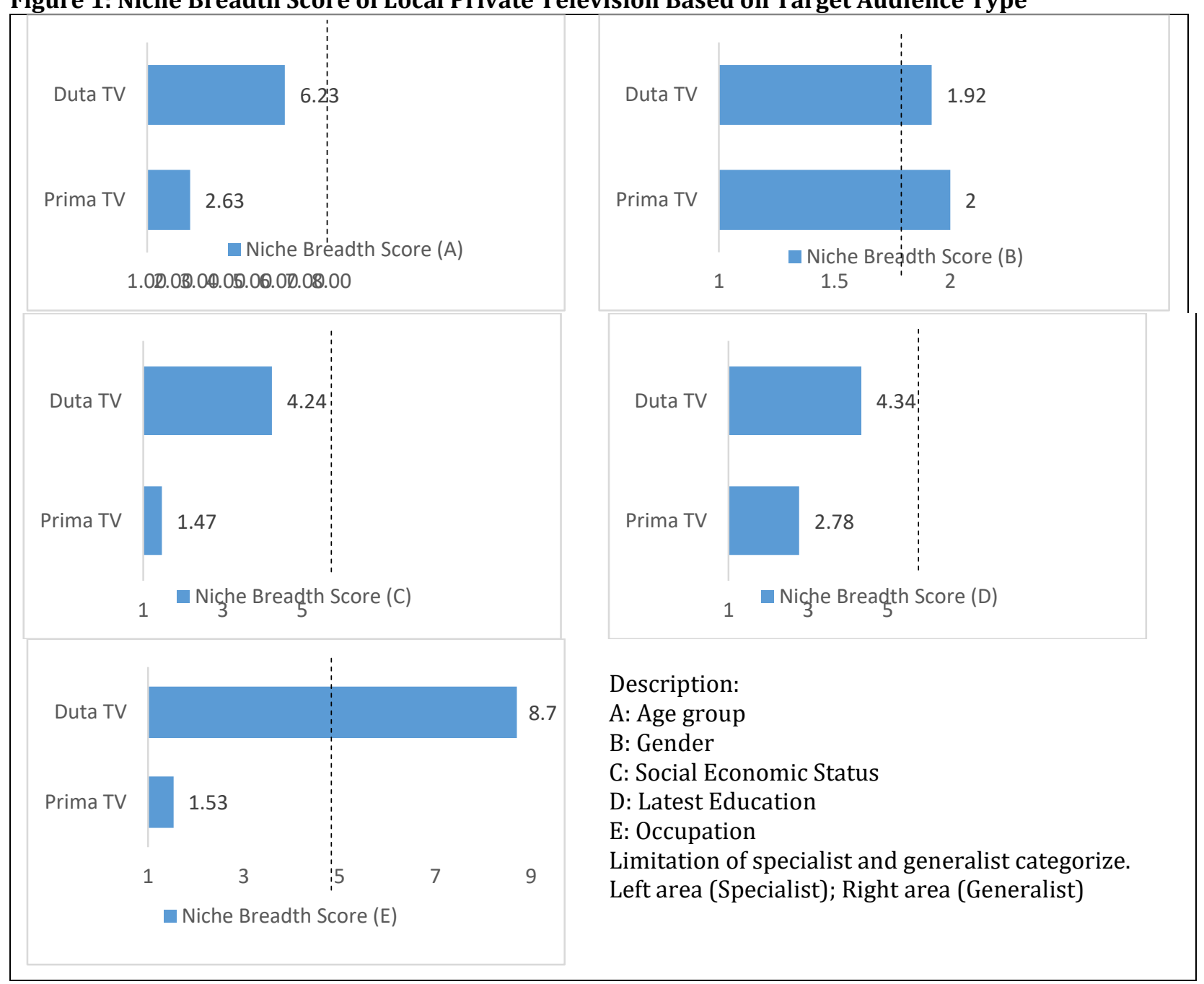

Figure 1 showed Duta TV had a fairly diverse target audience of all types, namely age group, gender, socialeconomic status, education, and occupation. Duta TV included television media that were in the generalist category on five types of target audiences with scores above the median value, while Prima TV included specialists in four types, namely age groups, social-economic status, education, and occupation with each score below the median value. As for the target audience of the gender, Prima TV is in the generalist category with a score exceeding the median value. Table 3 shows the target audience types percentage of each local private television media in South Kalimantan.

Table 3: The Target Audience Types Percentage of Each Local Private Television Media in South Kalimantan

\begin{tabular}{llll}
\hline $\begin{array}{l}\text { No. } \\
\text { A }\end{array}$ & $\begin{array}{l}\text { Category of Target Audience Types } \\
\text { Age Group }\end{array}$ & Duta TV & Prima TV \\
\hline 1 & $<15$ Years old & $3 \%$ & $0 \%$ \\
2 & $15-19$ Years old & $5 \%$ & $0 \%$ \\
3 & $20-24$ Years old & $10 \%$ & $20 \%$ \\
4 & $25-29$ Years old & $10 \%$ & $30 \%$ \\
5 & $30-34$ Years old & $17 \%$ & $0 \%$ \\
6 & $35-39$ Years old & $17 \%$ & $0 \%$ \\
7 & $40-50$ Years old & $25 \%$ & $50 \%$ \\
8 & $>50$ Years old & $13 \%$ & $0 \%$ \\
\hline
\end{tabular}




\begin{tabular}{llll}
\hline B & Gender & & \\
1 & Male & $40 \%$ & $50 \%$ \\
2 & Female & $60 \%$ & $50 \%$ \\
$\mathrm{C}$ & Social economic status (monthly expense) & & \\
1 & $>$ IDR 3.000.000 & $20 \%$ & $0 \%$ \\
2 & IDR 2.000.001 - IDR 3.000.000 & $30 \%$ & $20 \%$ \\
3 & IDR 1.000.001 - IDR 2.000.000 & $30 \%$ & $0 \%$ \\
4 & IDR 700.001 - IDR 1.000.000 & $10 \%$ & $0 \%$ \\
5 & IDR 500.001 - IDR 700.000 & $7 \%$ & $0 \%$ \\
6 & < IDR 500.000 & $3 \%$ & \\
D & Latest education & & $0 \%$ \\
1 & Did not complete elementary school & $4 \%$ & $0 \%$ \\
2 & Graduated from elementary school & $6 \%$ & $10 \%$ \\
3 & Graduated from junior high school & $15 \%$ & $10 \%$ \\
4 & Graduated from high school & $30 \%$ & $30 \%$ \\
5 & Academy & $30 \%$ & $50 \%$ \\
6 & College & $15 \%$ & $80 \%$ \\
$\mathrm{E}$ & Occupation & & $3 \%$ \\
1 & Civil Servant/ Army/ Police & $15 \%$ & $1 \%$ \\
2 & Private Employees & $10 \%$ & $5 \%$ \\
3 & Self-employed & $10 \%$ & $1 \%$ \\
4 & Retired & $10 \%$ & $0 \%$ \\
5 & Student & $10 \%$ & $10 \%$ \\
6 & College Student & $10 \%$ & $0 \%$ \\
7 & Housewife & $15 \%$ & $0 \%$ \\
8 & Other & $10 \%$ & \\
9 & Jobless & $10 \%$ & \\
\hline
\end{tabular}

According to the findings listed in Figure 1 and Table 3, the generalist category for Duta TV showed that the television media had diverse supporting resources in maintaining the viability of its media industry, while Prima TV with the specialist category, on four types of target audiences, shows that the television media has fairly limited supporting resources in terms of target audience type. Table 3 shows, for viewers with the age group category, Duta TV has a diverse target audience, namely 8 age groups ranging from $<15$ years to $>50$ years, while Prima TV only has 3 out of 8 age groups, namely 20-24 Years old, 25-29 Years old, and 40-50 Years old. For viewers in the gender category, both TV Ambassadors and Prima TV both have the same target audience, namely male and female viewers, what distinguishes it is that TV Ambassadors are dominated by a female audience with a size of $60 \%$ while Prima TV has both male and female audiences the same which is $50 \%$. Viewers with socioeconomic status groups, between Duta TV and Prima TV have different target audiences, where Duta TV has a target audience whose total monthly income starts from <IDR 500,000 to> IDR 3 million, while Prima TV has a target audience whose monthly income is between 1 million up to 3 million.

Likewise, with the Last Education and Employment category, Duta TV has a target audience with 6 target groups for recent education ranging from not completing elementary school to tertiary education and 9 target groups for employment, while Prima TV has 4 target groups for the latest education, starting from high school graduates to higher education, and 6 target groups for work, where the Prima TV audience is dominated by the Civil Servant group by $80 \%$. The percentage of viewers for the media audience, especially television as presented in Table 3 can be affected by several things, as Waddell \& Sundar (2020) discovered that view counters and comments affect media enjoyment through perceptions of audience size and collective opinion respectively. Breadth niche score that determines the category of both televisions based on the type of target audience has the same results as the findings of Atika et al. (2021) which revealed that Duta TV was in the generalist category and Prima TV was in the specialist category in terms of local content-based information program. The niche overlap score as presented in Table 4 shows the findings of the level of competition in seizing audiences between the two local private television media, namely Duta TV and Prima TV. 
Table 4: Niche Overlap Score of Local Private Television in South Kalimantan based on Target Audience Type

\begin{tabular}{lll}
\hline No. & Target Audience Type & Niche Overlap Score \\
\hline 1 & Age Group & 0,191 \\
2 & Gender & 0,020 \\
3 & Social Economic Status & 0,316 \\
4 & Latest Education & 0,170 \\
5 & Occupation & 0,479 \\
\hline
\end{tabular}

Table 4 shows that the niche overlaps score closest to zero is gender with a score of 0.020 , proving that the competition between Duta TV and Prima TV is high in seizing audiences based on their gender compared to the other four targets audience types. A high level of competition was found on both local private televisions based on local content-based information programs, where Duta TV and Prima TV had a high level of competition compared to other local private television couples in South Kalimantan (Atika et al., 2021).

\section{Conclusion and Recommendations}

The findings showed that Duta TV was in the generalist category and Prima TV was in the specialist category. The niche overlap scores differed between a number of target audience types, where the level of competition in seizing for viewers between the two televisions was quite high in the gender category compared to the other four types of target audiences, namely age group, socioeconomic status, recent education, and occupation. Based on the findings which show that local private television has a high level of competition for viewers, it is recommended to the media and regulators to maintain the sources of supporting media life for broadcasting sustainability in Indonesia, especially in South Kalimantan.

Acknowledgment: Our gratitude was conveyed to the Institute of Research and Community Service (LPPM) of Lambung Mangkurat University for funding the research in the Program of Lecturers Compulsory Research on PNBP funding in 2021.

\section{References}

Atika, A., Chandrabuwono, A. B. \& Maulina, N. (2021). Ekologi Media Televisi Swasta Berdasarkan Program Informasi Lokal Di Kalimantan Selatan. Prosiding Seminar Nasional Lingkungan Lahan Basah.

Atika, A. Chandrabuwono, A. B. \& Maulina, N. (2020). Ekologi Media Televisi Publik berdasarkan Program Informasi Lokal di Kalimantan Selatan. The Media Ecology of Public Television based on Local Information Programs in South Kalimantan, 18(02), 152-162.

Dimmick, J. W. (2008). Media Competition and Coexistence The Theory of the Niche. In Book. Routledge.

Dwinta Kusuma, G. (2017). Strategi Pt. Media Televisi Indonesia (Metro Tv) Sebagai "Media Televisi Berita" Dalam Menghadapi Persaingan Televisi Di Indonesia. UPN Veteran Yogyakarta.

Hamid, J. A. (2017). Strategi Pengembangan Net. Tv Dalam Menghadapi Persaingan Televisi Di Indonesia. Universitas Mercu Buana Jakarta.

Hidayati, N. (2009). Analisis Teori Niche berdasarkan Program Acara Radio pada 21 Radio di Kota Malang. University of Muhammadiyah Malang.

Irawan, R. E. (2012). Sisi Positif dan Negatif Persaingan Antarstasiun Televisi di Indonesia di Mata Penonton Televisi. Humaniora, 3(1), 173-180.

Katherine Chen, Y. N. (2019). Competitions between OTT TV platforms and traditional television in Taiwan: A Niche analysis. Telecommunications Policy, 43(9), 101793.

Li, S. C. S. (2017a). Replacement or complement: A niche analysis of Yahoo news, television news, and electronic news. Telematics and Informatics, 34(4), 261-273.

Li, S. C. S. (2017b). Television media old and new: A niche analysis of OTT, IPTV, and digital cable in Taiwan. Telematics and Informatics, 34(7), 10241037.

Morissan. (2015). Manajemen Media Penyiaran: Strategi Mengelola Radio \& Televisi. Kencana.

Primasanti, K. B. (2012). Manajemen Televisi Lokal: Kegamangan Yang Wajar. Jurnal Ilmiah Scriptura, 3(2), 161-171.

Priyowidodo, G. (2009). Menakar Kekuatan Dan Keunggulan Industri Televisi Lokal Di Era Otonomi. Jurnal 


\section{Journal of Social and Development Sciences (ISSN 2221-1152)}

Vol. 12, No. 2, pp. 20-26, June 2021

Ilmiah Scriptura, 2(1), 56-62.

Rinowati Na, R. N. (2012). Eksistensi Televisi Lokal (Kasus: Eksistensi TVKU Dalam Kompetisi Industri.

Waddell, T. F. \& Sundar, S. S. (2020). Bandwagon effects in social television: How audience metrics related to size and opinion affect the enjoyment of digital media. Computers in Human Behavior, 107. https://doi.org/10.1016/j.chb.2020.106270

Winanti Riesardhy, A. \& Herawati, F. A. (2013). Kompetisi Stasiun Televisi Swasta Nasional Berdasarkan Superiority Direction dan Superiority Magnitude. Jurnal ILMU KOMUNIKASI, 9(1), 34-55.

Yudiningrum, F. R. (2010). Iklan Dan Kompetisi Media (Analisis dan Aplikasi Teori Niche dalam Mengukur Kompetisi Penyiaran Iklan di Suara Kudus FM, Pamira FM, dan Yasika FM Bulan Februari 2010). Jurnal Komunikasi Massa, 3(2), 1-20. 